\title{
MEKANISME PERDAGANGAN EFEK SYARIAH DI INDONESIA
}

\author{
Linda Pratiwi \\ Pascasarjana Hukum Ekonomi Syariah \\ Universitas Islam Negeri Sunang Gunung Djati Bandung \\ Email : lndpr25@gmail.com
}

\begin{abstract}
ABSTRAK
Perkembangan lembaga keuangan syariah di Indonesia khususnya dalam bidang pasar modal syariah semakin menjadi primadona bagi para investor. Karena menjadi alternatif usaha go public yang aman. Pasar modal syariah merumuskan aturan-aturan tentang mekanisme transaksi. Dalam hal ini pasar modal syariah sebagai salah satu jenis pasar modal yang memperdagangkan komoditas berupa efek yang berjangka waktu panjang, pasar modal syariah hanya memperdagangkan reksadana Syariah, saham dan obligasi. Adapun proses penjualan dan pembelian efek Syariah seringkali dilakukan di Bursa Efek Indonesia yang sudah terdaftar.
\end{abstract}

Kata Kunci : Pasar Modal, Mekanisme, Efek 


\section{PENDAHULUAN}

Perdagangan di masa ini tidak hanya dilakukan di pasar konvensional. Kini perdagangan surat berharga, valuta asing dan saham lainnya pun telah dilakukan oleh banyak orang. Secara umum pengertian pasar modal merupakan pasar abstrak sekaligus pasar konkret dengan barang yang diperjualbelikan adalah dana yang bersifat abstrak, danbentuk konkretnya adalah lembar surat-surat berharga di bursa efek.

Adapun setiap individu atau perusahaan yang ingin bergabung pada pasar atau bursa ini tidak bebas keluar masuk seperti pada pasar-pasar lainnya, setiap perusahaan atau individu yang ingin bergabung harus memenuhi beberapa persyaratan. Seperti telah diatur dalam pasal 30 ayat 1 UU tentang Perizinan Perusahaan Efek yang isinya bahwa "Yang dapat melakukan kegiatan usaha sebagai Perusahaan Efek ialah Perseroan yang telah memperoleh izin usaha dari Bapepam", dan persyaratan tersebut terdapat di ayat 3 yang isinya "Pihak yang melakukan kegiatan usaha sebagai Perantara Pedagang Efek, Penjamin Emisi Efek, dan Manajer Investasi hanya untuk Efek yang bersifat utang yang jatuh temponya tidak lebih dari satu tahun, sertifikat deposito, polis asuransi, Efek yang diterbitkan atau dijamin Pemerintah Indonesia, atau Efek lain yang ditetapkan oleh Bapepam tidak diwajibkan memperoleh izin usaha sebagai Perusahaan Efek". Untuk memperjelas ketentuan yang dimaksud dalam undang-undang tersebut maka Ketua Bapepam mengeluarkan keputusan bernomor Kep- 02 /PM/1996, tanggal 17 Januari 1996 tentang perizinan bursa efek. $^{1}$

\section{PEMBAHASAN}

\section{Pasar Modal dan Efek Syariah}

Pasar modal merupakan perdagangan instrument keuangan (sekuritas) jangka panjang, antara lain dalam bentuk modal sendiri (stock) maupun utang (bonds) baik yang diterbitkan oleh pemerintah (public authorities) maupun oleh perusahaan swasta (private sector). Sedangkan pasar modal syariah merupakan tempat atau sarana bertemunya penjual dan pembeli instrumen keuangan syariah yang dalam berinteraksi berpedoman pada ajaran islam dan menjauhi hal-hal yang dilarang, seperti penggelapan dan penipuan. $^{2}$

Pasar modal sesuai dengan Undangundang Nomor 8 Tahun 1995 tentang Pasar Modal (UUPM) ialah kegiatan yang bersangkutan dengan Penawaran Umum dan perdagangan Efek." "Oleh krena itu maka pasar modal syariah dapat diartikan sebagai kegiatan dalam pasar modal sebagaimana yang diatur dalam UUPM yang tidak bertentangan dengan prinsip syariah. Pasar modal syariah bukanlah suatu sistem yang terpisah dari sistem pasar modal secara keseluruhan. Secara

\footnotetext{
${ }^{1}$ Ketua Bapepam mengeluarkan keputusan bernomor Kep- 02 tahun 1996

2 Prof. Dr. Ahmad Rodoni dan Prof Dr. Abdul Hamid, Lembaga Keuangan Syariah, (Zikrul Hakim, Jakarta Timur) HIm 123.

3 Undang-undang Nomor 8 Tahun 1995 tentang Pasar Modal
}

Volume II/ Nomor 01/ Januari 2020 
umum praktik Pasar Modal Syariah tidak beda jauh dengan pasar modal konvensional, namun terdapat beberapa karakteristik khusus Pasar Modal Syariah yaitu bahwa produk dan mekanisme transaksi tidak bertentangan dengan prinsip-prinsip Syariah.

Sedangkan pengertian Bursa Efek menurut J.Bogen ialah suatu sistem yang terorganisasi dengan mekanisme resmi untuk mempertemukan penjual dan pembeli efek secara langsung atau melalui wakil-wakilnya. Efek Syariah ialah Efek sebagaimana dimaksud dalam Undangundang Pasar Modal dan peraturan pelaksanaannya yang akad maupun cara penerbitannya memenuhi Prinsip-prinsip Syariah di Pasar Modal. ${ }^{4}$

Mekanisme Transaksi Perdagangan Efek Syaiah

Penawaran umum (public offering)

Perusahaan menawarkan Efek kepada masyarakat dengan cara melakukan Penawaran Umum. Penawaran Umum ialah kegiatan penawaran Efek yang dilakukan oleh Emiten dalam wilayah Republik Indonesia dengan menggunakan media masa dan ditawarkan kepada masyarakat berdasarkan tata cara yang diatur dalam UU No 8 Tahun 1995 tentang Pasar Modal. Adapun Emiten merupakan pihak yang melakukan Penawaran Umum. Latar belakang perusahaan melakukan Penawaran Umum antara lain keinginan perusahaan untuk memperoleh tambahan

\footnotetext{
4 http://www.ojk.go.id/sharia-capital-id di akses tanggal 19 April 2019 pada pukul 13.35 WIB
}

sumber pendanaan dari masyarakat. Penambahan modal itu biasanya dipergunakan untuk pembiayaan kegiatan operasional, pembayaran utang, pembelian barang modal, pendanaan modal kerja dan akuisisi perusahaan. ${ }^{5}$

Selain mendapat keuntungan berupa tambahan modal atau dana untuk mengembangkan usaha, terdapat beberapa akibat lain dari go public yaitu :

a. Emiten menjadi lebih dikenal masyarakat

b. Emiten dituntun untuk bekerja lebih professional karena emiten mendapatkan pengawasan dari banyak pihak, seperti analis, bursa efek, termasuk para pemegang saham. ${ }^{6}$

Proses Penawaran Umum dibagi menjadi beberapa tahap.

\section{Tahap Persiapan}

Tahapan ini merupakan awal dalam mempersiapkan segala sesuatu yang berkaitan dengan proses Penawaran Umum. Hal yang pertama kali dilakukan oleh Calon Perusahaan Tercatat ialah melakukan Rapat Umum Pemegang Saham untuk meminta persetujuan para pemegang saham dalam rangka Penawaran Umum saham. Setelah mendapat persetujuan, Calon Perusahaan yang sudah Tercatat Melakukan penunjukan terhadap

https://www.ojk.go.id/Files/box/BukuSakuOJK.pdf diakses tanggal 19 April 2019 pada pukul 14.01 WIB

6 Abdul Manan, Prof.Dr, SH., S.IP., M.Hum, Aspek Hukum Dalam Penyelenggara Investasi Di Pasar Modal Syariah Indonesia Edisi Pertama (Kencana, Jalarta: 2009) HIm 68 
Lembaga dan Profesi Penunjang Pasar Modal, antara lain:

a. Penjamin Emisi (Underwriter) adalah pihak yang paling banyak terlibat dalam membantu Calon Perusahaan Tercatat dalam rangka penerbitan saham dengan menyiapkan berbagai dokumen, memberikan Penjaminan atas penerbitan Efek dan membantu membuat Prospektus.

b. Akuntan Publik (Auditor Independen) ialah pihak yang bertugas untuk melakukan audit atau pemeriksaan atas Laporan Keuangan Perusahaan Tercatat dan Calon Perusahaan Tercatat.

c. Penilai Independen yang merupakan pihak yang melakukan penilaian atas Aktiva Calon Perusahaan Tercatat dan memenentukan nilai waj̣ar dari Aktiva tersebut.

d. Konsultan Hukum yakni pihak yang memberikan pendapat dari segi hukum (legal opinion).

e. Notaris yakni pihak yang membuat akta-akta perubahan Anggaran Dasar, akta perjanịian-perjanjian dalam rangka Penawaran Umum dan juga notulen-notulen rapat.

f. Biro Administrasi Efek yakni bertugas untuk mengadministrasikan pemesanan saham dan mengadministrasikan kepemilikan saham.

Tahap Pengajuan Pernyataan Pendaftaran

Dalam tahap ini, Calon Perusahaan Tercatat melengkapi dokumen pendukung untuk menyampaikan Pernyataan Pendaftaran kepada OIK sampai dengan
OIK menyatakan bahwa Pernyataan Pedaftaran telah menjadi efektif.

Tahap Penawaran Saham

Tahap ini merupakan tahap utama karena Calon Perusahaan Tercatat menawarkan sahamnya kepada investor. Investor boleh membeli saham melalui agen penjual yang telah ditunjuk. Masa penawaran umum berlaku minimal 1 hari kerja dan maksimal 5 hari kerja.

Perlu diingat bahwa seluruh keinginan investor atas saham Calon Perusahaan Tercatat dapat dipenuhi seluruhnya jika terjadi kelebihan permintaan Sebagai contoh, saham yang ditawarkan ke investor melalui Pasar Perdana sebanyak 500 juta saham, sementara permintaan pembelian saham dari seluruh investor sebesar 550 juta saham. Dalam hal investor tidak mendapatkan saham yang dipesan melalui Pasar Perdana, maka investor tersebut dapat membeli saham tersebut di Pasar Sekunder ialah pasar dimana saham tersebut telah dicatatkan dan diperdagangkan di Bursa Efek.

Tahap Pencatatan Saham di Bursa Efek

Setelah selesai penjualan saham di Pasar Perdana, selanjutnya saham tersebut diperdagangkan di Bursa Efek Indonesia. ${ }^{7}$

7 Andri Soemitra, Bank dan Lembaga Keuangan Syariah, (Jakarta: Kencana, 2010), cet ke-2, hlm 129 Volume II/ Nomor 01/ Januari 2020 
Skema Penawaran Umum ${ }^{8}$

\begin{tabular}{|c|c|c|c|c|}
\hline Sebelum E & nisi & Emisi & Sesua & ah Emisi \\
\hline $\begin{array}{c}\text { Intern } \\
\text { Perusahaan }\end{array}$ & BAPEPAM & $\begin{array}{l}\text { Pasar } \\
\text { Primer }\end{array}$ & $\begin{array}{c}\text { Pasar } \\
\text { Sekunder }\end{array}$ & Pelaporan \\
\hline | & | & & | & | \\
\hline $\begin{array}{l}\text { 1. Perencanaa } \\
\mathrm{n} \text { go public } \\
\text { 2. RUPS } \\
\text { 3. Menuju } \\
\text { Underwrite } \\
\text { r, profesi } \\
\text { penunjang, } \\
\text { Lembaga } \\
\text { penunjang } \\
\text { 4. Mempersia } \\
\text { pkan } \\
\text { dokumen. } \\
\text { 5. Konfirmasi } \\
\text { sebagai } \\
\text { agen } \\
\text { penjual oleh } \\
\text { penjamin } \\
\text { 6. Kontrak } \\
\text { pendahulua } \\
\text { n dengan } \\
\text { bursa efek } \\
\text { 7. Penandatan } \\
\text { ganan } \\
\text { perjanjian- } \\
\text { perjanjian } \\
\text { 8. Public expore }\end{array}$ & $\begin{array}{l}\text { 1. Pernyataan } \\
\text { pendaftaran } \\
\text { 2. Expose } \\
\text { terbatas di } \\
\text { BAPEPAM } \\
\text { 3. Tanggapan } \\
\text { atas } \\
\text { - Kelengkapa } \\
\text { n dokumen } \\
\text { Kecukupan } \\
\text { dan } \\
\text { kejelasan } \\
\text { informasi } \\
\text { - Keterbukaa } \\
\text { n (aspek } \\
\text { hukum, } \\
\text { akuntansi, } \\
\text { keuangan } \\
\text { dan } \\
\text { manajemen) } \\
\text { Komentar } \\
\text { tertulis } \\
\text { dalam } \\
\text { waktu } 45 \\
\text { hari } \\
\text { 5. Pernyataan } \\
\text { pendaftaran } \\
\text { yang efektif }\end{array}$ & $\begin{array}{l}\text { 1.Penawaran } \\
\text { umum } \\
\text { 2.Penjatahan } \\
\text { kepada } \\
\text { modal oleh } \\
\text { indikasi } \\
\text { penjamin } \\
\text { emisi } \\
\text { 3.Distribusi } \\
\text { efek } \\
\text { kepada } \\
\text { pemodal } \\
\text { secara } \\
\text { elektronik }\end{array}$ & $\begin{array}{l}\text { 1. Emiten } \\
\text { mencatatk } \\
\text { an } \\
\text { sahamnya } \\
\text { di Bursa } \\
\text { Efek } \\
\text { 2. Perdagang } \\
\text { an dibursa } \\
\text { efek }\end{array}$ & $\begin{array}{l}\text { 1. Laporan } \\
\text { berkala } \\
\text { misalnya } \\
\text { laporan } \\
\text { bulanan, } \\
\text { kuartalan } \\
\text { dan } \\
\text { tahunan } \\
\text { 2. Laporan } \\
\text { kejadian } \\
\text { penting } \\
\text { dan } \\
\text { relevan } \\
\text { misalnya } \\
\text { akuisisi } \\
\text { pergantia } \\
\text { n direksi }\end{array}$ \\
\hline
\end{tabular}

8 Heri Sudarsono. Bank dan Lembaga Keuangan Syariah. (Yogyakarta: Ekonisia-Kampus FE UII tahun 2003) HIm 23 
Perdagangan Efek Syariah di Bursa Efek

\section{Indonesia (BEI)}

Setelah membeli Efek melalui Penawaran Umum (Pasar Perdana), investor dapat menjual kembali Efek miliknya tersebut untuk memperoleh keuntungan (capital gain) dan memungkinkan investor lain untuk membeli Efek tersebut melalui Pasar Sekunder. Untuk dapat bertransaksi Efek melalui Bursa Efek, masyarakat harus menjadi nasabah sebuah Perusahaan Efek Anggota Bursa terlebih dahulu, karena order untuk beli maupun jual Efek harus disampaikan melalui Perusahaan Efek Anggota Bursa, dan kemudian Anggota Bursa menginput order tersebut ke sistem perdagangan Bursa Efek. ${ }^{9}$

Bursa efek bekerija sama dengan Lembaga Kliring dan Penjaminan (LKP) dan Lembaga Penyimpanan dan Penyelesaian (LPP) menyelenggarakan operasional bursa dengan menyediakan sistem dan sarana perdagangan Efek, termasuk peraturan bursa dan sistem dalam rangka melakukan pengawasan perdagangan efek antara lain untuk mencegah, mendeteksi kegiatan dan tindakan yang tidak sesuai dengan prinsip syariah. Atas kegiatan menyelenggarakan operasional bursa, bursa Efek mengenakan dapat dikenakan biaya (uj̣rah). ${ }^{10}$

Lembaga Kliring dan Penjaminan (LKP) adalah Pihak yang menye-

9

https://www.ojk.go.id/Files/box/BukuSakuOJK.pdf diakses tanggal 20 maret 2019 pukul 13.22

10 Ida Musdafia Ibrahim, Jurnal Ekonomi dan Hukum Islam, Mekanisme dan Akad Pada Transaksi Saham di Pasar Modal Syariah Vol. 3, No. 2 Syariah tahun 2013 ISSN: 2088-6365

38 Jurnal Ilmu Akuntansi dan Bisnis Syariah lenggarakan jasa kliring dan penjaminan penyelesaian Transaksi Bursa ${ }^{11}$ atau disebut novasi atas Perdagangan Efek yang dilakukan Anggota Bursa. Pelaksanaan novasi ini dilaksanakan berdasarkan prinsip hawalah bil ujrah. Oleh karenanya LKP mengenakan biaya (ujrah) kliring dan penjaminan dari Anggota Bursa/Kliring atas jasa yang dilakukannya. Lembaga Penyimpanan dan Penyelesaian (LPP) adalah_Pihak yang menyelenggarakan kegiatan Kustodian sentral atau penyimpanan dan penyelesaian atas Perdagangan Efek bagi bank kustodian, perusahaan efek dan pihak lain. Untuk jasa penyimpanan dan penyelesaian, LPP mengenakan biaya (ujrah) dari Perusahaan Efek. ${ }^{12}$

Perdagangan Efek Bersifat Ekuitas, di Pasar Reguler Bursa Efek adalah pasar dimana perdagangan efek di Bursa Efek dilaksanakan berdasarkan proses tawar menawwar yang berkesinambungan (bai' al-musawamah) oleh anggota Bursa efek dan penyelesaian administrasinya dilakukan pada har bursa ketiga setelah terjadinya perdagnagan efek di bursa efek. ${ }^{13}$ Bursa Efek menetapkan aturan bahwa perdagangan Efek hanya boleh dilakukan oleh Anggota Bursa Efek. Anggota Bursa Efek adalah Perusahaan Efek yang telah memperoleh izin usaha dari Badan Pengawas Pasar Modal dan

\footnotetext{
${ }^{11}$ Fatwa Dewan Syariah Nasional No: 80/DSNMUI/III?2011 Tentang Penerapan Prinsip Syariah Dalam Mekanisme Perdagangan Efek Syariah Bersifat Ekuitas Dipasasr Regular Bursa Efek Tentang Ketentuan Umum Poin 8

12 Ibid Ketentuan Umum Poin 9

${ }^{13}$ Ibid Ketentuan Umum Poin 4 Volume II/ Nomor 01/ Januari 2020
} 
Lembaga Keuangan (Bapepam dan LK) sebagai Perantara Pedagang Efek dan telah memperoleh persetujuan keanggotaan bursa untuk mempergunakan sistem dan sarana bursa dalam melakukan kegiatan Perdagangan Efek di Bursa Efek sesuai dengan peraturan Bursa Efek Indonesia. ${ }^{14}$

Perdagangan efek tersebut dilaksanakan berdasarkan prinsip ijarah atas penyediaan sistem dan sarana perdagangan kepada Anggota Bursa Efek. Penjual dan Pembeli Efek yang bukan Anggota Bursa Efek dalam melaksanakan Perdagangan Efek harus melalui Anggota Bursa Efek. Akad antara penjual atau pembeli efek yang bukan Anggota Bursa Efek dengan Anggota Bursa menggunakan akad juealah, yaitu janj̣i atau komitmen untuk memberikan imbalan tertentu atas pencapaian hasil (natijah) yang ditentukan dalam pekerjaan. Harga pasar dari Efek Bersifat Ekuitas Sesuai Prinsip Syariah harus mencerminkan nilai valuasi kondisi yang sesungguhnya dari aset yang menjadi dasar penerbitan Efek tersebut (nilai intrinsik) atau sesuai dengan mekanisme pasar yang efisien, teratur dan wajar serta tidak dapat direkayasa.

Ketentuan Hukum Mekanisme Perdagangan Efek Bersifat Ekuitas di Pasar Reguler Bursa Efek Indonesia yakni:

a. Perdagangan Efek di Pasar Reguler Bursa Efek menggunakan akad jual beli (bai').

b. Akad jual beli dinilai sah ketika terjadi kesepakatan pada harga

${ }^{14}$ Ibid Ketentuan Umum Poin 6 serta jenis dan volume tertentu antara permintaan beli dan penawaran jual.

c. Pembeli dapat menjual efek setelah akad jual beli dinilai sah walaupun penyelesaian administrasi transaksi pembeliannya dilaksanakan di kemudian hari berdasarkan prinsip qabdh hukmi.

d. Efek yang boleh diperdagangkan hanya Efek Bersifat Ekuitas Sesuai Prinsip Syariah.

e. Harga dalam jual beli tersebut boleh ditetapkan berdasarkan kesepakatan yang mengacu pada harga pasar wajar melalui mekanisme tawar menawar yang berkesinambungan.

f. Dalam Perdagangan Efek tidak boleh melakukan kegiatan dan/atau tindakan yang tidak sesuai dengan prinsip syariah. ${ }^{15}$

\section{Tahapan Perdagangan Efek Syariah di Bursa Efek}

Perdagangan efek di bursa dapat dibagi menjadi beberapa tahap,dimulai dari proses pembukaan rekening efek dan penyampaian order dari nasabah kepada Anggota bursa, pemrosesan order, pelaksanaan transaksi (matching), proses kliring, serta penjaminan dan penyelesaian transaksi. Secara umum tahapan tersebut berlaku untuk semua jenis efek yang diperdagangkan di Bursa Efek Indonesia

15 Ida Musdafia Ibrahim, Jurnal Ekonomi dan Hukum Islam, Mekanisme dan Akad Pada Transaksi Saham di Pasar Modal Syariah Vol. 3, No. 2 Syariah tahun 2013. 
(BEI), perbedaannya hanya terletak pada spesifikasi transaksi seperti fraksi harga dan batasan harga yang diperkenankan. ${ }^{16}$ Uraian berikut ini merupakan proses perdagangan efek di BEI yang difokuskan pada mekanisme dan spesifikasi transaksi saham:

\section{Pembukaan Rekening}

Sebelum melakukan jual beli efek, calon nasabah harus membuka rekening terlebih dahulu di perusahaan efek yang menjadi Anggota Bursa dengan cara mengisi formulir pembukaan rekening. Nasabah tersebut dapat merupakan nasabah langsung dari $\mathrm{AB}$ ataupun dari Perusahaan Efek bukan Anggota Bursa yang menjalin kerja sama dengan Perusahaan efek anggota bursa. ${ }^{17}$

\section{Tahap Pemrosesan}

Order yang telah disampaikan oleh PE AB dalam sistem perdagangan baik secara manual, remote maupun online akan diproses oleh sistem JATS secara elektronik. Proses order tersebut dibedakan pada masing-masing pasar yang berbeda sesuai dengan pilihan pasar dari nasabah baik pasar regular, tunai maupun pasar negosiasi. Perdagangan Efek sukuk di BEI hanya dilakukan pada pasar regular dengan waktu penyelesaian tiga hari bursa setelah transaksi terjadi $(\mathrm{T}+3)$.

16 Bapepam-LK, Kajian Pasar Sekunder Efek Syari'ah di Bursa Efek Indonesia, (Jakarta:BapepamLK,2010).

17 http://digilib.uinsby.ac.id/3183/9/Bab\%205.pdf diakses tanggal 20 Maret 2019 pukul 20.22 WIB. 40 Jurnal Ilmu Akuntansi dan Bisnis Syariah

\section{Pelaksanaan Transakasi}

Pelaksanaan perdagangan efek di BEI dilakukan dengan menggunakan fasilitas Jakarta Automated Trading System Next Generation (JATSNextG). Perdagangan efek di BEI hanya dapat dilakukan oleh Perusahaan efek anggota bursa yang juga menjadi Anggota Kliring (AK) di KPEI ${ }^{18}$. Perusahaan Efek yang menjadi anggota bursa bertanggung jawab terhadap seluruh transaksi yang dilakukan di bursa,baik untuk kepentingan sendiri maupun untuk kepentingan nasabah. Terhadap transaksi yang dilakukan melalui BEI, maka setiap Perushaan Efek Anggota Bursa mengenakan biaya kepada nasabahnya atas penggunaan jasa sistem berupa biaya transaksi, kliring dan penyelesaian transaksi sebesar 0,03 persen dari nilai transaksi yang dibagi secara proporsional kepada KPEI, KSEI dan BEI 19. Sedangkan biaya transaksi yang dikenakan oleh Perusahaan Efek Anggota Bursa (PE AB) kepada nasabahnya berkisar antara 0,2\% sampai dengan 0,5 persen dari nilai transaksi, baik untuk transaksi jual maupun transaksi beli.

KPEI menyediakan jasa penjaminan penyelesaian transaksi bursa bagi

18 Kliring Penjaminan Efek Indonesia (KPEI) sebagai salah satu Self-Regulatory Organization (SRO) dibawah pengawasan Otoritas Jasa Keuangan (OJK), diberi kewenangan untuk membuat dan menerapkan peraturan terkait fungsinya sebagai Lembaga Keliring Penjaminan (LKP) di pasar modal Indonesia.

19 Kustodian Sentral Efek Indonesia (KSEI) merupakan Lembaga Penyimpanan dan Penyelesaian(LPP) di Pasar Modal Indonesia yang menyediakan layanan jasa Kustodian sentral dan penyelesaian transaksi Efek yang teratur, wajar, dan efisien, sesuai amanat Undang-Undang Nomor 8 Tahun 1995 tentang Pasar Modal.

Volume II/ Nomor 01/ Januari 2020 
Anggota Keliring (AK) yang bertransaksi di Bursa Efek Indonesia (BEI). Jasa penjaminan merupakan jasa untuk memberikan kepastian atas terpenuhinya hak dan kewajiban AK yang timbul dari transaksi di BEI. Selain itu fungsi penjaminan bertujuan memberikan kepastian atas terselenggaranya transaksi bagi AK yang sudah memenuhi kewajibannya, waktu penyelesaian transaksi, dan penurunan frekuensi kegagalan penyelesaian transaksi sehingga pada akhirnya dapat meningkatkan kepercayaan investor untuk bertransaksi di pasar modal Indonesia. KPEI juga berkewaj̣iban untuk menjamin penyelesaian transaksi di bursa dan langsung mengambil alih tanggung jawab Anggota Keliring (AK) yang gagal memenuhi kewajiban terkait dengan transaksi bursa yang dilakukannya. ${ }^{20}$

${ }^{20} \mathrm{https} / / /$ ekbis.sindonews.com/read/658653/3 


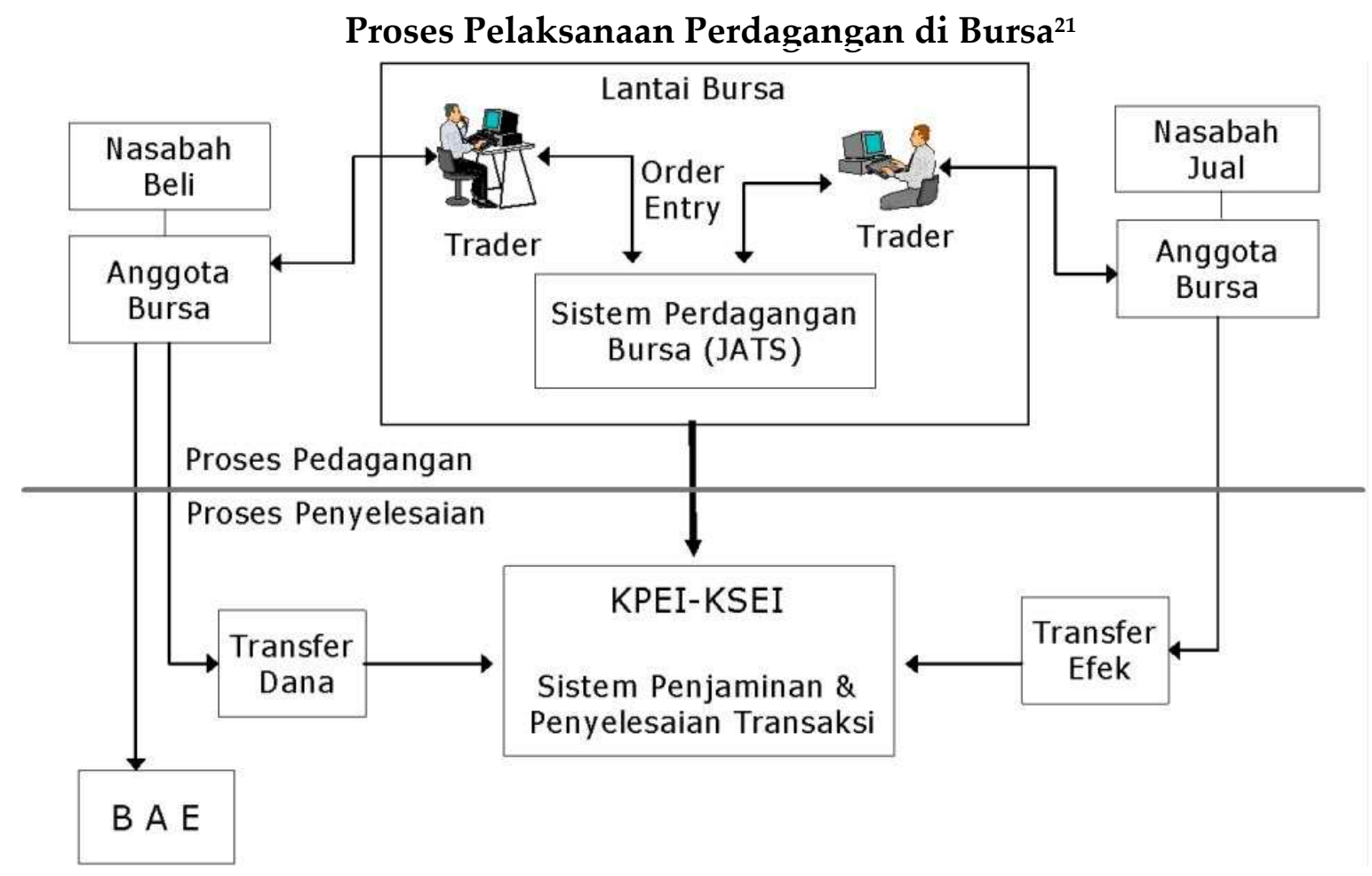

Proses Pelaksanaan Perdagangan secara Remote ${ }^{22}$

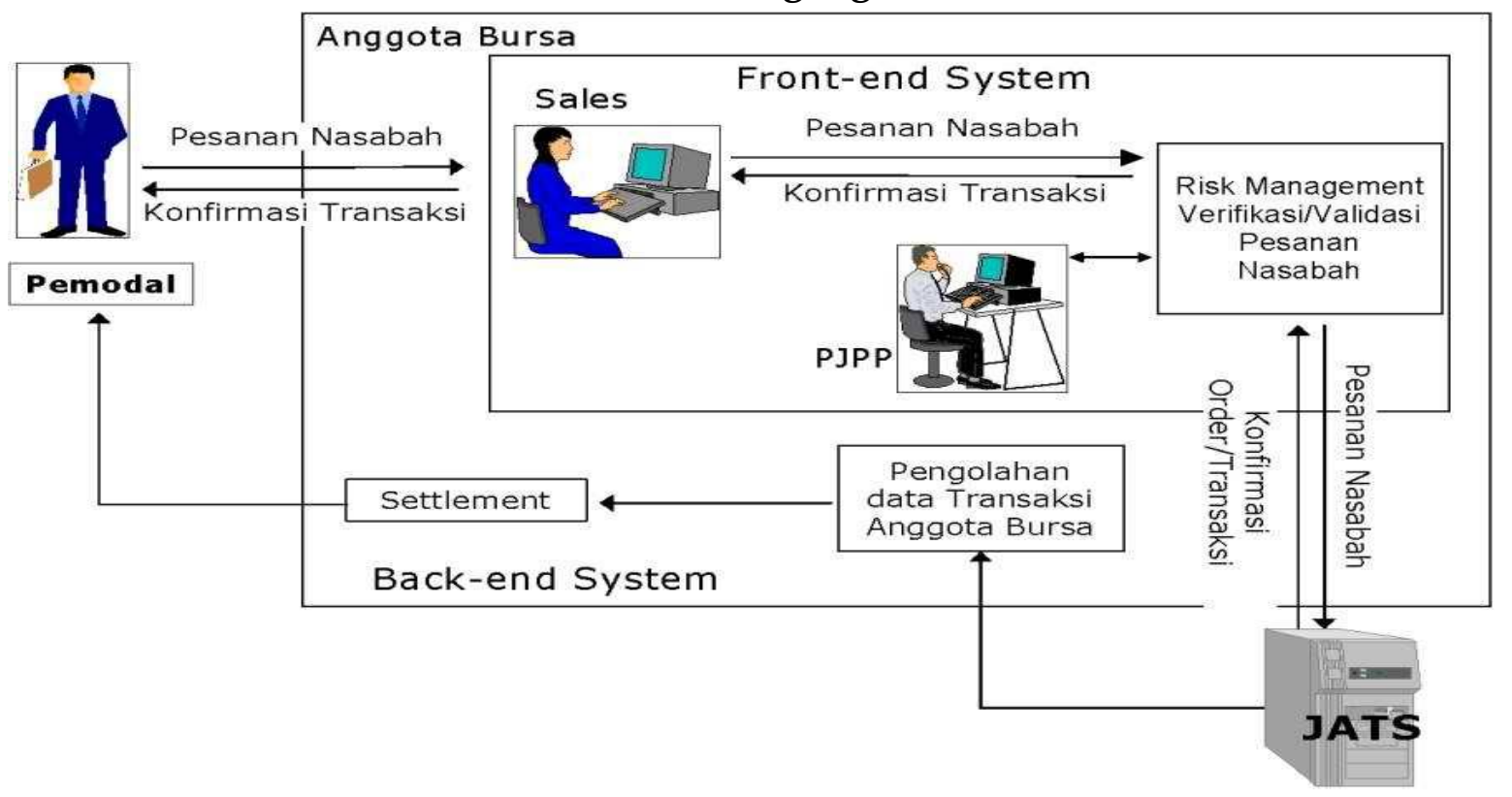

${ }^{21}$ www.idx.co.id diakses tanggal 10 april 2019 pukul 20.00 WIB

22 ibid 
Berdasarkan tabel di atas bahawa proses perdangan efek dijelaskan sebagai berikut:

1. Menjadi Nasabah di Perusahaan Efek

Pada bagian ini, seseorang yang akan menjiadi investor terlebih dahulu menjadi nasabah atau membuka rekening di salah satu broker atau Perusahaan Efek. Setelah resmi terdaftar menjadi nasabah, maka investor dapat melakukan kegiatan transaksi.

2. Order dari nasabah

Pada tahap ini, perintah atau order dapat dilakukan secara langsung dimana investor datang ke kantor broker atau order disampaikan melalui sarana komunikasi seperti telpon atau sarana komunikasi lainnya.

3. Diteruskan ke Floor Trader

Setiap order yang masuk ke broker selanj̣utnya akan diteruskan ke petugas broker tersebut yang berada di floor trader (lantai bursa).

4. Masukkan order ke Iakarta Automated Tranding System (JATS) Floor trader akan memasukkan semua order yang diterimanya ke dalam sistem komputer Jakarta Automated Tranding System (JATS). Di floor trader (lantai bursa) terdapat beberapa terminal IATS yang menjadi sarana entry order-order dari nasabah. Semua order yang masuk ke sistem JATS dipantau baik oleh lantai bursa, petugas di kantor broker dan investor. Dalam tahap ini terdapat komunikasi antara pihak broker dengan investor agar dapat terpenuhi tujuan order yang disampaikan investor baik untuk jual dan beli. Termasuk pada tahap ini berdasarkan perintah investor, floor trader melakukan beberapa perubahan order seperti perubahan harga penawaran, dan beberapa perubahan lainnya.

\section{Transaksi Terjadi (matched)}

Pada tahap ini order yang dimasukkan ke sistem IATS bertemu dengan harga yang sesuai dan tercatat di sistem JATS sebagai transaksi yang telah terjadi, dalam arti sebuah order beli atau jual telah bertemu dengan harga yang cocok. Pada tahap ini pihak lantai bursa atau petugas di kantor broker akan memberikan informasi kepada investor bahwa order yang disampaikan telah terpenuhi.

6. Penyelesaian Transaksi (settlement) Tahap akhir dari sebuah siklus transaksi merupakan penyelesaian transaksi. Investor belum mendapatkan hak-haknya karena pada tahap ini dibutuhkan beberapa proses seperti kliring dan pemindahbukuan. Sehingga akhirnya hakhak investor terpenuhi, seperti investor yang menjual saham akan mendapatkan uang, sementara investor yang melakukan pembelian saham akan mendapatkan saham. Di Bursa Efek Indonesia proses penyelesaian transaksi berlangsung selama 3 hari. Artinya jika mela- 
kukan transaksi hari ini (T) maka hak-hak kita akan dipenuhi selama 3 hari bursa berikutnya, atau dikenal dengan istilah $\mathrm{T}+3 .{ }^{23}$

\section{SIMPULAN}

Dari beberapa penjelasan diatas maka penulis merumuskan bahwa mekanisme perdagangan bursa efek adalah sebagai berikut:

Sebelum dapat melakukan transaksi, terlebih dahulu investor harus menjadi nasabah di perusahaan Efek atau kantor broker. Di BEI terdapat sekitar 120 perusahaan Efek yang menjadi anggota BEI. Pertama kali investor melakukan pembukaan rekening dengan mengisi dokumen pembukaan rekening. Di dalam dokumen rekening tersebut memuat identitas nasabah lengkap (termasuk tujuan investasi dan keadaan keuangan) serta keterangan tentang investasi yang akan dilakukan.

Nasabah atau investor dapat melakukan order jual atau beli setelah investor disetujui untuk menjadi nasabah di perusahaan Efek yang bersangkutan. Umumnya setiap perusahaan Efek mewajibkan kepada nasabahnya untuk mendepositkan sejumlah uang tertentu sebagai jaminan bahwa nasabah tersebut layak melakukan jual beli saham.

Dilihat dari prosesnya, maka urutan perdagangan saham atau Efek lainnya dapat dijelaskan sebagai berikut:

23 Musdalifah Aziz, Sri Mintarti, dan Maryam Nadir, Manajemen Investasi Fundamental, Teknikal, Perilaku Investor Dan Return Saham (Deepublish. Yogyakarta: 2015) hlm 33.

44 Jurnal Ilmu Akuntansi dan Bisnis Syariah
1. Menjadi Nasabah di Perusahaan Efek

2. Order dari nasabah

3. Diteruskan ke Floor Trader

4. Masukkan order ke JATS

5. Transaksi Terjadi (matched)

6. Penyelesaian Transaksi (settlement) 


\section{DAFTAR PUSTAKA}

\section{Buku}

Abdul Manan, Prof.Dr, SH., S.IP., M.Hum, Aspek Hukum Dalam Penyelenggara Investasi Di Pasar Modal Syariah Indonesia Edisi Pertama (Kencana, Jalarta: 2009)

Ahmad Rodoni dan Abdul Hamid, Lembaga Keuangan Syariah, (Zikrul Hakim, Jakarta Timur)

Andri Soemitra, Bank dan Lembaga Keuangan Syariah, Cetakan ke-2 (Jakarta: Kencana, 2010)

Heri Sudarsono. Bank dan Lembaga Keuangan Syariah. (Yogyakarta: Ekonisia-Kampus FE UII tahun 2003)

Musdalifah Aziz, Sri mintarti, dan Maryam Nadir, Manajemen Investasi Fundamental, Teknikal, Perilaku Investor Dan Return Saham (Deepublish. Yogyakarta: 2015).

Bapepam-LK, Kajian Pasar Sekunder Efek Syari'ah di Bursa Efek Indonesia, (Jakarta: Bapepam-LK,2010).

Fatwa Dewan Syariah Nasional No: 80/DSN-MUI/III?2011 Tentang Penerapan Prinsip Syariah Dalam Mekanisme Perdagangan Efek Syariah Bersifat Ekuitas Dipasasr Regular Bursa Efek

Undang-Undang Nomor 8 Tahun 1995 tentang Pasar Modal

\section{Jurnal}

Ida Musdafia Ibrahim, Jurnal Ekonomi dan Hukum Islam, Mekanisme dan Akad Pada Transaksi Saham di Pasar Modal Syariah Vol. 3, No. 2 Syariah tahun 2013.

\section{Internet}

http://www.ojk.go.id/sharia-capital-id di akses tanggal 19 April 2019 pada pukul 13.35 WIB

https://www.ojk.go.id/Files/box/BukuSakuOJK.pdf diakses tanggal 19 April 2019 pada pukul 14.01 WIB

https://www.ojk.go.id/Files/box/BukuSakuOJK.pdf diakses tanggal 20 Maret 2019 pukul 13.22

http://digilib.uinsby.ac.id/3183/9/Bab\%205.pdf diakses tanggal 20 Maret 2019 pukul 20.22 WIB.

https://ekbis.sindonews.com/read/658653/39/mekanisme-perdagangan-saham-di-lantaibursa-1342165392 diakses tanggal 19 Maret 2019 Pukul 22.00 WIB.

www.idx.co.id diakses tanggal 10 april 2019 pukul 20.00 WIB 
linda pratiwi 